\title{
Motivation Acts As An Innovative Tool In Organizational Development And Change: A Case Study Of Female Employees In Karachi University
}

\author{
Mariya Baig \\ Department of Examination \\ University of Karachi \\ Muhammad Siddique \\ PN School of Logistics \\ PNS Karsaz \\ Abu Zar Wajidi \\ Institute of Health \& Business Management \\ Jinnah Sindh Medical University
}

\begin{abstract}
The study primarily accentuates on the need of motivation of female employees for organizational development and change that is an innovative tool and may be used in any organization; and also highlights the importance of motivation which acts as a catalyst for the progress of the female employees in various organizations. The data collection from 116 respondents was done on a convenience basis by means of a structured and verified scale. Respondents from different departments of Karachi University were chosen among whom the questionnaires were circulated and a suitable statistical test was applied on the independent variable of female employees' motivation and the dependent variable of organizational development and change to find the statistical significance of the hypotheses for possible acceptance or rejection. Results of the analysis indicate that female employees in Pakistan generally are demotivated to be employed in an organization due to family restrictions, workplace harassment and lack of motivation at places where they are employed, and this affects their performance and creates hurdles the way of organizational development and change. The research will help the relevant institution to support women's productive role in employment that will help in poverty alleviation.
\end{abstract}

Keywords: Motivation, Female employees, Organizational Development, Change.

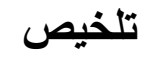

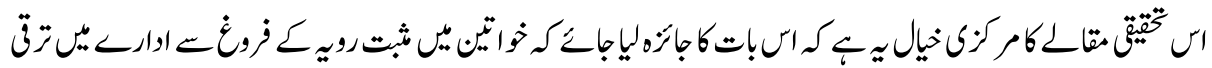

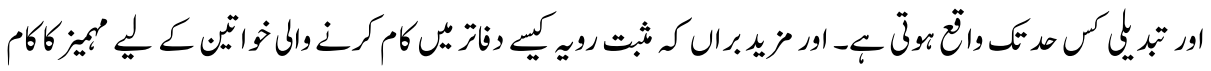

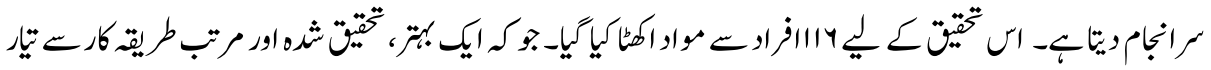




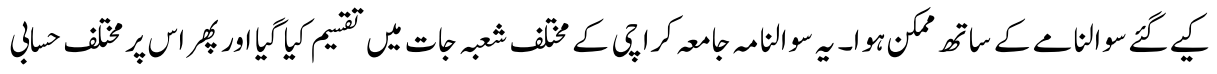

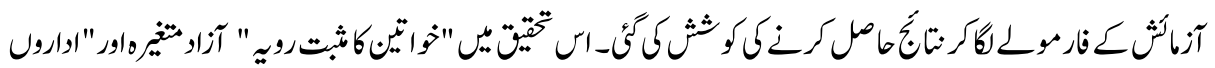

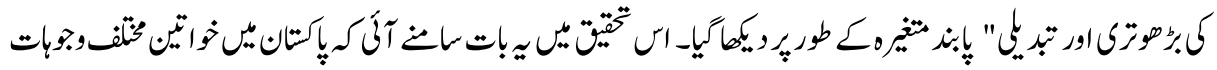

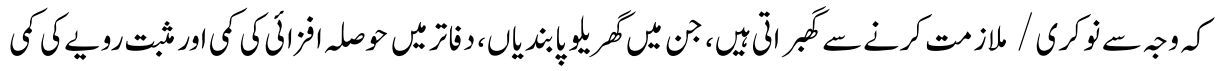

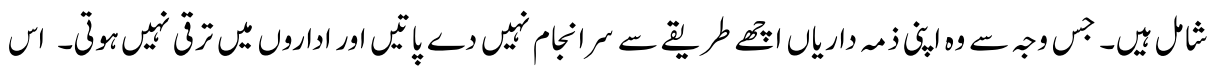

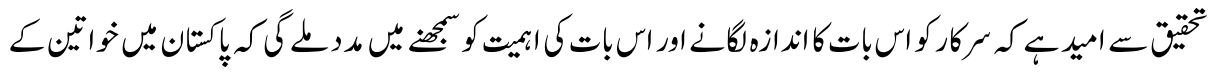

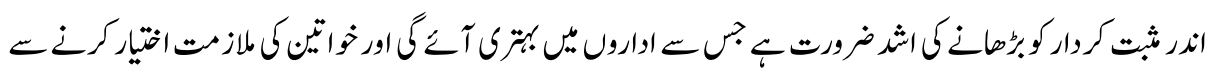

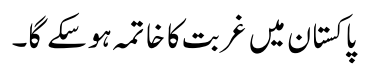

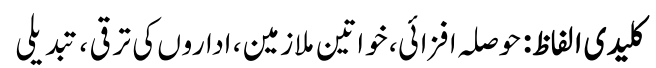

\section{Introduction}

We are living in the 21 stcentury and one of the pinnacles of this epoch is the transformation of the world into a global village, where the distance has virtually ended. But the division between the developed and developing world persists. Developing countries are often classified with low per capita income, low level of human capital, low literacy rate, abnormal amounts of destitution and undernourishment, dominance of informal sector, stagnant performance of institution, low level of industrialization etc., whereas the developed countries are characterized by high per capita income, rapid industrialization, better performance of socio-economic indicators, high literacy rate, strong public institutional role, etc. Many studies show that motivation is a big tool that helps to the working women in their working performance, but it is also indicated that some serious social issues may be the cause for demotivation of such working women. In Pakistan, the common issues faced by the working women and they may be the causes for the discontinuation of their jobs are women harassments, gender-biased, family biased, and geographical biased, etc. and due to such problems working women are demotivated and unable to perform their duties easily. Therefore, this research work is an endeavor to inspect the role of motivation as an innovative tool in the development and change of organizations. This research study will find out the ways and means by which the female employees, in public sector universities, could use motivation as innovative tools for organizational development, and explain the different styles of management that could increase motivation in the female employees. The study shall also explain how the motivated female employees are beneficial for organizations, alongside defining the contributions and the limitations of this research, 
and recommending in which direction future researches on the concerned issue must proceed.

For many supervisors and managers, the crucial query is how their female employees can be kept passionate and motivated towards work. This is because motivated female employees generate the highest outcome, which is to the greatest advantage of organizations situated in the market as well as the open associations. A successful manager is the one who can keep its subordinates and female employees satisfied and motivated towards their jobs. The increased competition in the labor market reveals that organizations are facing challenges in retaining their female employees due to the limited scope of growth in careers and opportunities for progress.

There are many reasons that women have to participate in earning activities of a family, for example, in some cases, only women supporters are for their families, and sometimes, due to the continuously devaluation of Pakistani currency and rising trend of inflation and its negative impact on the lives of common people, ultimately, a large number of women have been engaged with corporate sector in different organizations. This tendency is more in big cities like Karachi.

Keeping in mind the above situations, most of the women apply for jobs as fresh candidates. They have no job experience and have to face many difficulties not only due to the new environment but also due to other reasons. For example, it is the common observation in Pakistan that women are ignored for higher studies and the majority of women are either uneducated or less educated. Similarly, in daily life, there are many issues faced by the working women that maybe the big hurdles for in continuation of their jobs. These issues are women harassments, gender-biased, family biased, and geographical biased, etc. and due to such problems working women are demotivated and unable to perform their duties smoothly. That is why it is the utmost need to research in this field.

The female employees' job attitude and job behavior have a major role in the success, failure, as well as survival of any organization. Therefore, organizations are spending the major portion of their budget on research and development to know about the behavior, as well as to maintain the satisfaction of job in their female employees, otherwise, the employee gets frustrated which results in low productivity and less development in the organization. To select a proper strategy to motivate the employee, the data from female employees of the University of Karachi have been collected to search their needs, wants, behavior and attitude towards the organization. Data have been collected from various departments, such as (DRA) Office of the Deputy Registrar Academics, (DRE) Office of the Deputy Registrar Establishment, (DRG) Office of the Deputy Registrar General, 
(BASR) Board of Advanced Studies and Research, Affiliation Department, Examination Department, Public Relation Office, Estate Office, and Human Resource Management Office. Data have also been collected from Faculty of Social Sciences and Arts, Faculty of Science, Faculty of Law, Faculty of Management and Administrative Science, Faculty of Engineering, Faculty of Pharmacy, Faculty of Islamic Studies.

Most of the female employees who are working in different organizations are less educated but they do their jobs due to urgent needs and sometimes they become demotivated due to their personal and family issues, management and official issues and most common of the ethical issues such as women harassments, gender-biased, family biased, and geographical biased, etc. Therefore, in such cases women need motivation for their better performance so that they may become positive part of the organizations and this act may bring a positive change in the working environment and the organizations may get the better results.

This study will find out that how female employees can counter their demotivation and make their organizations more developed and changed. Is it true that motivation works as an innovative tool for female employees in organizational development and change? This study is a complete effort aiming to guide the managers of the organizations where female employees are performing their duties with zeal and spirit. The study provides the guidelines to the managers of the corporate sector where female employees are working but they are demotivated due to some ethical issues persistent in these organizations and the result female employees may not perform their duties properly. Therefore, if such female employees are provided a peaceful and respectful working environment and the management try to resolve their genuine issues, such female employees will motivate and perform better for organizational development and change.

The scope of the study is to focus on the ethical issues of female employees working in University of Karachi in various departments who are demotivated by the rude behavior of the management and to point out such ethical issues that must be resolved for the motivation of female employees and also for the organizational development and change. The study will promote the positive effects of motivational tool used by the management for increasing the efficiency of the female employees working in the corporate sector. Such motivational techniques are beneficial not only to overcome their ethical issues but also to help in organizational development and change. The study is beneficial for potential organizations and for those organizations which are already working not only at government level but also at private, and semi-private level, situated in Karachi, and it is true that for the whole corporate sector in Pakistan. Moreover, the non-profit organization where female employees are engaged can also implement the concept of motivation for 
the better cure of female issues and the organizational development and change. The researchers have done their maximum efforts to include the opinions of the female employees engaged in various departments of the University of Karachi. The researchers are highly depended on respondents' responses and there may be the chances of wrong responses if the participates had misguided to the researchers due to any fear and favor regarding the management. Therefore, until and unless such barriers are not removed, the chances of wrong data collection from any organizations may not be corrected.

\section{Review of Literature}

The term motivation is characterized as a power that drives and stimulates human activity to carry out a task. It's the intrinsic qualities of a being that activate him towards the achievement of objectives. After defining the term motivation now it is important to feature why it is an innovative tool in the development of any organization such as the University of Karachi. It has been built up that motivation essentially influences workers' execution in an association and that it is the directors' task to motivate the demotivated employees (Re'em, 2010). Over the world, the administrators are attempting to accomplish the objectives set for the organization by enhancing the employees' performance at work. A definitive objective of the administrators today is to enhance the productivity and viability into the beneficial result (Mitchell, 1982). Execution at work is not driven by motivation alone yet inspiration serves as a noteworthy determinant to adjust the dimension of execution (Ahlstrom, Bruton, \& Garry, 2009). The skills of an employee, his decision making, inspiration towards work and workplace and work culture makes up his work performance (Mitchell, 1982).

The significance of motivation can be effectively comprehended by the given condition where if there is no driving force to work, there will be zero execution independent of how dexterous the work might be and how better comprehension of function the employees have. The workplace additionally is of no significance when the workers have zero motivation towards work (Mackenzie \& Gordon, 2016). It does not matter whether the employees have a big learning gap in their lives. With the possession of high motivation, employees can perform better at work. It is also noted that employees with lack of experience and knowledge, their smart attitude towards learning and solving new tasks at work, exceeds their shortcoming (Landy \& Conte, 2010). It is seen that motivated female employees are less fussy and rebellious and committed towards their work and organization and if each female member in a group assignment ought to perform best regardless of how her team members are performing, then the outcome of the project would be amazing (Jurkiewicz, Massey \& Brown, 1998). Motivated female employees are the positive externality and such female employees as compared to the demotivated 
female employees can perform better (Wajidi \& Tabassum, 2016). Motivated female employees feel more relaxed and less stressed; their positive attitude towards challenges and work always keeps them motivated and optimistic (Robison, 2010). Motivation has proven to be an important determinant in shaping the image of any organization. One of the factors that endow an organization with long term success, growth and efficacy is the presence of motivated female employees (Javed \& Javed, 2013). Their motivation and enthusiasm towards work innovation in problem-solving, responsiveness towards challenges, approachability towards their customers and clients and commitment with their respected organizations is what makes an organization be it a public sector organization such as the University of Karachi or any private sector organization, a successful workplace (MAN Forum, 2009).

Administrators assume a critical job in keeping their female workers persuaded towards their employments. To achieve the best result from the female representatives, the directors must cooperate with their workers frequently. The manager should constantly provide feedback to show a keen interest in their employees. Getting constant feedback from the manager influences the employees to improve their performance (Maduka \& Okafor, 2014). Constructive criticism also has a positive impact on the workers' execution. Their useful analysis causes the female representatives to perform better and create enhanced yield. In any case, if the directors disregard their female representatives and the significance of their work, the female representatives may get outraged and give not exactly their potential towards work (Bruce \& Pepitone, 1998). If the female representatives feel that they are not given significance, their work is not valued and they are not esteemed by their administrators and their managers than they are compelled to leave the working environment. Ignoring female representatives and not esteeming their administration makes an unfriendly effect on workers' persuasive dimension towards their work and working environment (MAN Forum, 2009). Managers trust that they are improving the situation in keeping their specialists and female representatives inspired towards work (Jurkiewicz, Massey \& Brown, 1998); (MAN Forum, 2009). In some cases, managers have neglected to comprehend the subject of motivation and ineffectively suggests persuasive practices in their zones (Accel-Team, 2010).

A decent supervisor should intelligently pick among controlling and propelling their female representatives to the greatest advantage of an association. It is seen that before joining association specialists are profoundly energetic yet when they begin working and feels that the work environment they have joined is not up to their desire they switch their occupations. Unsupportive work environment results in numerous resignations (Bevan, Barber, \& Robinson, 1997). It is additionally clear that there is little proof available on the idea that female workers leave the association on account of 
disappointment even with the chances of development given by the organization (MAN Forum, 2009).

The managers are encouraged to consistently keep track of the achievement and disappointment of their female employees (Stajkovic \& Luthans, 2003). By estimating the work performance, a manager can find the level of proficiency. Unfortunately, in the University of Karachi, the non-teaching female employees are demotivated due to the lack of appropriate training of the directors and bosses towards motivating their female workers. The complex motivational theories are a reason why managers fail to motivate their employees (Latham, 2007). It has been settled that paying little respect to the issues between the upper management and middle management, the real issues and the demotivation factors among non-teaching female employees are never talked properly by the concerned bosses (Balk, 1974); (Bowey, 2005). In public sector institutes like the University of Karachi, the non-teaching female staff is demotivated due to gender-biased, female harassments and also due to some personal issues (Wajidi \& Tabassum, 2016). The private sector institutes motivate their employees in a better way for the prosperity of the general public (Wright, 2001). Leonard (2009) disclosed that it is hard to persuade the common female workers. Buelens \& Broeck (2007) stated that female representatives are normally stereotyped for being sluggish and torpid, less dedicated to work and working hours (Wright, 2001). The managers and supervisors working in the organizations such as the University of Karachi can motivate and can make prompt their subordinates and juniors by involving them in the decision making the process, by creating a friendly working environment (Christensen, 2002). The female employees can also be kept interested in seeking organizational benefits foremost by offering them periodical increments in salary, bonuses, allowances, fringe benefits and other forms of compensations (Vandenabeele, 2007). Financial prizes, appreciation letters, giving additional increments are the general ways of motivation in the (MAN Forum, 2009); (Behn, 1995).

Motivation is a main driving force behind every action taken and for most of the female employees, motivational factors such as rewards and incentives serve as the core drivers behind their motivation (Habil, Allah \& Shehadah, 2017). (Danish \& Usman, 2010) explained that the dissimilarity in work motivation between the workers involved in private and in public sectors is manifest. The evidence from Pakistan suggests that public sector female employees have a high level of work motivation paralleled to the private sector female employees (Nawaz \& Muazzam, 2015). The workforce of the public sector is often generalized as selfish and self-interested female employees as compared to female employees working in the private sector, however, this notion is proven to be wrong as they are equitably altruistic and less self-centered (Khattak \& Sayeed, 2000). It 
is also found that for the public sector female employees' supportive working surroundings and hierarchical level are major motivation drivers (Shah et al., 2016). For female employees of both the sectors, factors such as salary, independence, inclination towards work and workable environments are the main motivators (Irum, Sultana, Ahmed \& Mehmood, 2012).

Zia-ur-Rehman et al., (n.d.) highlighted that that the fiscal reward assumes a significant job in inspiring the female representatives. There exists a positive connection between execution-related pay and occupation inspiration for open part female workers (Masood Asim, 2013).

Malik, Nawab, Naeem \& Danish, (2010) stated that in Punjab, Pakistan- on the basis of micro-level study- that, owing to better human resource management practice in training, teamwork, performance appraisal, employee participation and in compensation practices, the universities belonging to the public sector have performed comparatively better than the ones in the private sector (Shah et al., 2016). The literature extensively agrees that both inherent and extrinsic rewards are important for an organization to keep its female employees motivated and satisfied with their work and responsibilities (Khalid, Irshad \& Mahmood, 2010). Empirically it is proven that for civil servants' extrinsic awards are of less importance, they are also less motivated by the self-development but the public sector female employees are well driven and motived under workable surroundings as paralleled to private female employees (Iqbal, Arif \& Abbas, 2011). It is also observed that the ubiquity of workplace tiers of job designation is the most significant aspect in elucidating dissimilarities in motivation between public servants and private female employees (Buelens \& Broeck, 2007).

Buelens \& Broeck (2007) explored that there are three kinds of female employees' private female employees, civil servants, and para-public sector female employees. The findings of the study conclude that there are marginal differences in basic values between all kinds of female employees. The para-public female employees give less importance to growth opportunities and intrinsic rewards than private and public sector female employees (My Linh Nguyen, 2017). They place a high value in contributing to society; they are believed to be altruistic and less self-centered as compared to public sector workers and private sector female employees. It is also observed that the private sector female employees are more determent towards their workplace as compare to civil servants and para-public sector female employees and that the para-public female employees are least committed to their organization as compared to other sector female employees (Mashhura Sidikova, 2011). It is also argued that the public sector such as the University of Karachi, because of less motivation of its workers towards their 
organizations and their job description will eventually lead the public sector to a threshold level of motivated, dedicated and committed female employees (Lyons, Duxbury, \& Higgins, 2006). Motivation is broadly categorized into three types; publicservice motivation, mission motivation, and task motivation. For civil servants, it is found that public-service motive is the highest motivator (Perry et al., (2006).

\section{Research Design and Methodology}

The non-teaching female employees of the University of Karachi were taken as the sample population of this study. For data collection, the convenience sampling method was adopted.

The data of 116 female respondents were taken as a sample size from the total nonteaching female staff from a total of 163 female employees engaged in the same category in the University of Karachi. 116 respondents of the sample population were requested to complete the structured questionnaire voluntarily. The sample size was calculated as: Sample Size $=n=N / 1+N(e)^{2}$. This formula was suggested by Yamane (1667:886). The abbreviations used in the formula mean:

$\mathrm{n}=$ Sample size

$\mathrm{N}=$ Population size

$e=$ precision or sample error

Statistically, it means that there is $95 \%$ confidence interval and there may be a chance of $5 \%$ error inthe sample population mean.

Hence, the sample size, based on the above formula, $\left\{n=N / 1+N(e)^{2}=\{163 / 1+163\right.$ $(5 \%)\}$ will be 116 respondents.

\section{Data Collection Technique and Instrument}

The data were collected from 116 non-teaching female employees at random basis from different departments of the University of Karachi. The respondents were qualified from matric to post-graduation level, engaged in clerical jobs to officer cadres in various departments. The data were collected by means of well developed, structured and verified scale and closed-ended questionnaire (Appendix-A). All of the questionnaires were distributed among the respondents in different departments of the Karachi University personally by the researchers. The responses show that the majority of female employees were demotivated due to various personal and ethical issues. The data were collected in 20 days because most of the respondents were busy at that moment and they handed over the questionnaires later on. After that, responses were fed into the Statistical Package for Social Sciences (IBM SPSS Statistics 16) version 16 for further analysis and evaluation. 
The non-teaching female employees and administrators of the sample population were requested formal consent to permit utilizing their data in the investigation. The reactions of the respondents were coded to keep up the mystery and secrecy of the data. The access to information was additionally restricted just to the specialists required for better analysis and investigation. To check the internal reliability of the instrument, Cronbach's alpha was calculated. The value of Cronbach's Alpha was 0.715 i.e. greater than 0.70 . It is suggested the accepted edge of reliability should be at least 0.70 . It shows that our instrument is reliable.

\section{Hypotheses}

H1 0 Motivation does not work as an innovative tool for female employees in organizational development and change.

$\mathbf{H 1}_{\mathbf{A}}$ Motivation works as an innovative tool for female employees in organizational development and change.

\section{Data Analysis and Findings}

This section covers two parts. Part-A represents the data demographics and Part-B represents the data analysis of the study.

\section{Part-A: Data Demographics}

The demographic part covers the details about the personal information of the respondents randomly collected as sample size for the study. The gender of the study were only 116 non-teaching female employees who were in the age groups of 30 years to 55 years, qualified from matriculation to post-graduation level, having job experience of 2 years to 19 years, working in different departments of the University of Karachi, were selected as the sample population for the study.

\section{Gender of the Respondents}

The total employees of the University of Karachi can be divided into two major categories. That is, teaching staff and non-teaching staff. Under the category of teaching staff or faculty, there are 316 male employees and 363 female employees that makes a total of 679 teaching faculty while under the category of non-teaching staff or faculty, there are 1954 male employees and 163 female employees that makes a total of 2117 employees. But, the researchers have selected for this study only the segment of nonteaching female employees. It means that only female genders $(100 \%$ of female employees) of non-faculty staff have been considered for this study. Accordingly, the 
researchers have chosen a sample size of 116 non-teaching female employees as indicated in table-1, and also shown in figure-1 below:

\section{Table - 1}

Gender

\begin{tabular}{|l|l|c|c|c|c|}
\hline & & Frequency & Percent & Valid Percent & Cumulative Percent \\
\hline Valid & Female & 116 & 100.0 & 100.0 & 100.0 \\
\hline
\end{tabular}

Figure-1: Gender Record

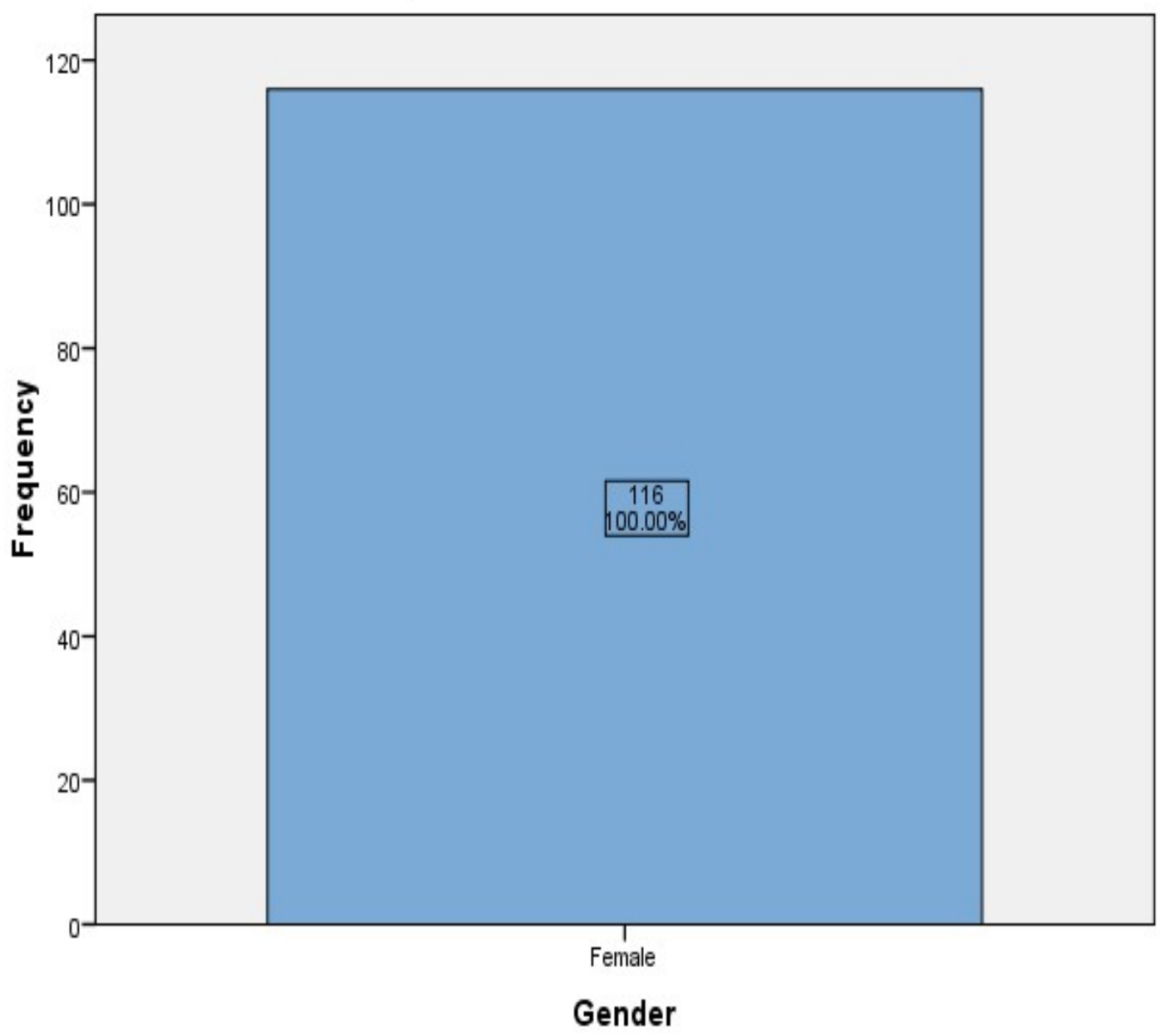

\section{Age of the Respondents}

Figure No. 02, below, indicated the age groups of the sample population of the nonteaching female employees, working in various departments in the University of Karachi. 
Accordingly, the non-teaching female employees who have reached the age of 43 years are 9 in numbers that cover the $7.76 \%$ from the total of 116 non-teaching female employees of the sample population, engaged in various departments in the University of Karachi. The graphical presentation of age records of 116 non-teaching female employees with the strength of female non-teaching employees in concerning age groups with the related percentages is shown in Figure No. 02. The minimum age group consists of 30 years and only 3 female employees fall in this category who are of $2.59 \%$ of the sample population. Similarly, other age groups have been presented below:

Figure-2 : Age Records

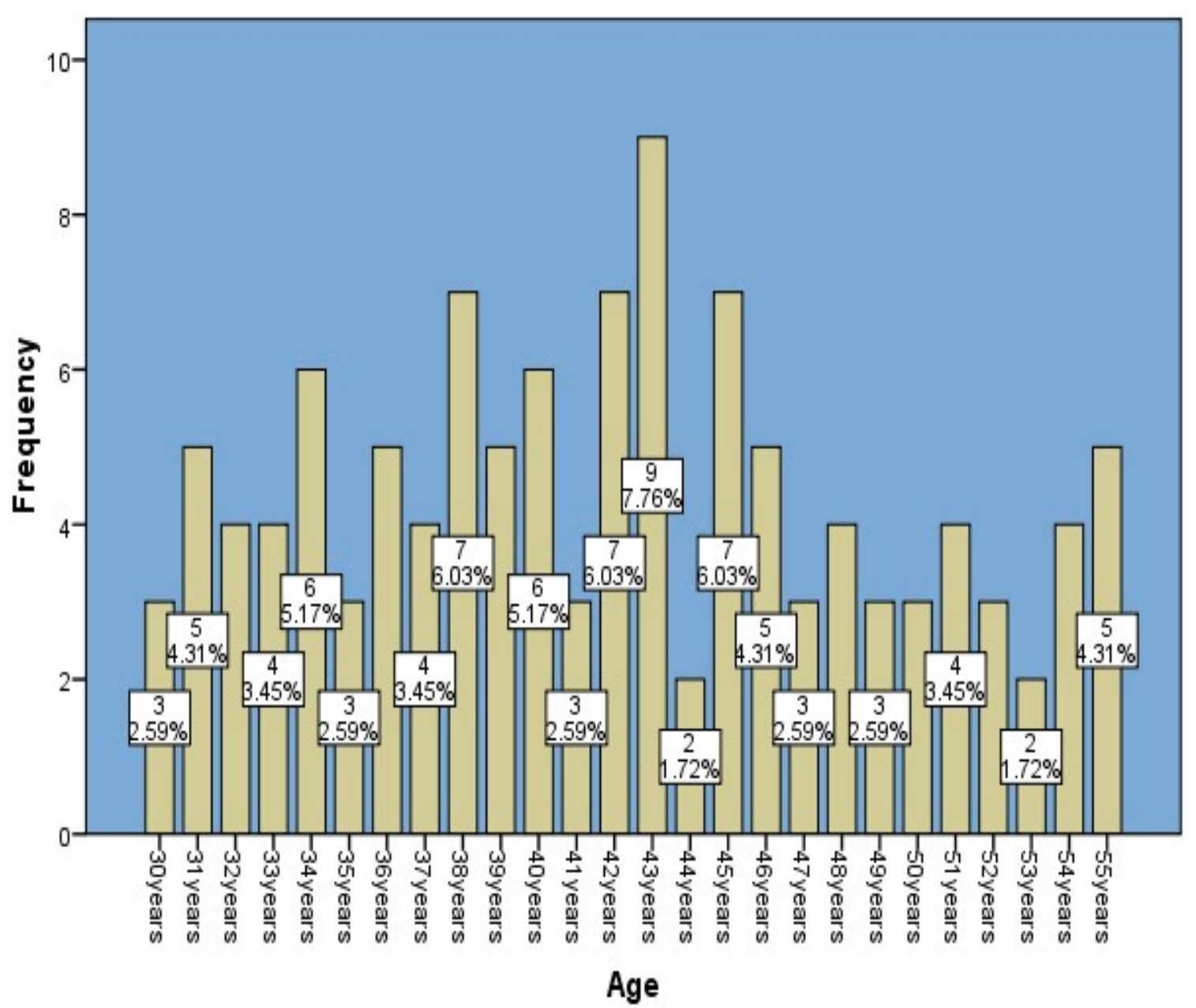




\section{Education of the Respondents}

The education records of respondents are shown in table- 2 and figure- 3 below. Accordingly, among the total sample population of 116 non-teaching female employees, 23 females are just Matric that constitute $19.8 \%$ of the sample population, 41 females are Intermediate that cover $35.3 \%$ of the sample population, 24 females are Graduates that is of $20.7 \%$, and 28 females are counted as Post Graduates that are of $24.1 \%$ of the sample population of the study.

Table - 2

Education

\begin{tabular}{|l|l|c|c|c|c|}
\hline & & Frequency & Percent & $\begin{array}{c}\text { Valid } \\
\text { Percent }\end{array}$ & $\begin{array}{c}\text { Cumulative } \\
\text { Percent }\end{array}$ \\
\hline \multirow{3}{*}{ Valid } & Matric & 23 & 19.8 & 19.8 & 19.8 \\
\cline { 2 - 6 } & Intermediate & 41 & 35.3 & 35.3 & 55.2 \\
\cline { 2 - 6 } & Graduate & 24 & 20.7 & 20.7 & 75.9 \\
\cline { 2 - 6 } & Post Graduate & 28 & 24.1 & 24.1 & 100.0 \\
\cline { 2 - 6 } & Total & 116 & 100.0 & 100.0 & \\
\hline
\end{tabular}

Figure-3 : Education Records

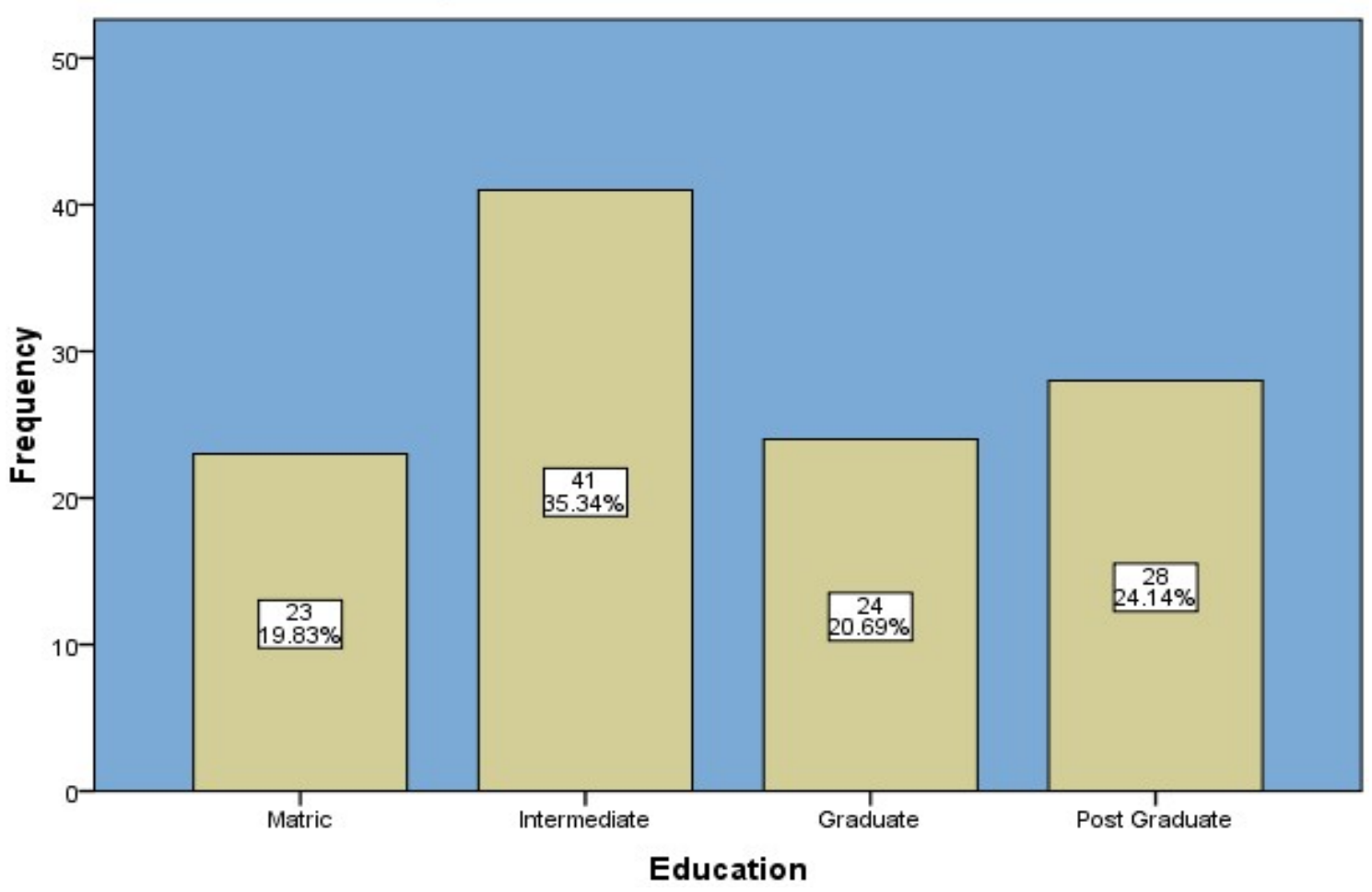




\section{Experience of the Respondents}

Experience records of non-teaching female employees are displayed in figure-4 below. Among the sample population of 116 non-teaching female employees, 17 females have 5 years of job experience that is of $14.66 \%$ of the sample population and it is the highest percentage of non-faculty female staff from the sample segment in the University of Karachi. Similarly, the next number of the higher experience is of 14 non-faculty female staff who have 8 years of job experience that is of $12.07 \%$ of the total sample population as indicated in figure-4. There is one female employee who has 19 years of services that constitutes $0.86 \%$ of the total sample population in the study and in the similar way the job experience records of other non-teaching female employees have been depicted graphically in the figure-4, below:

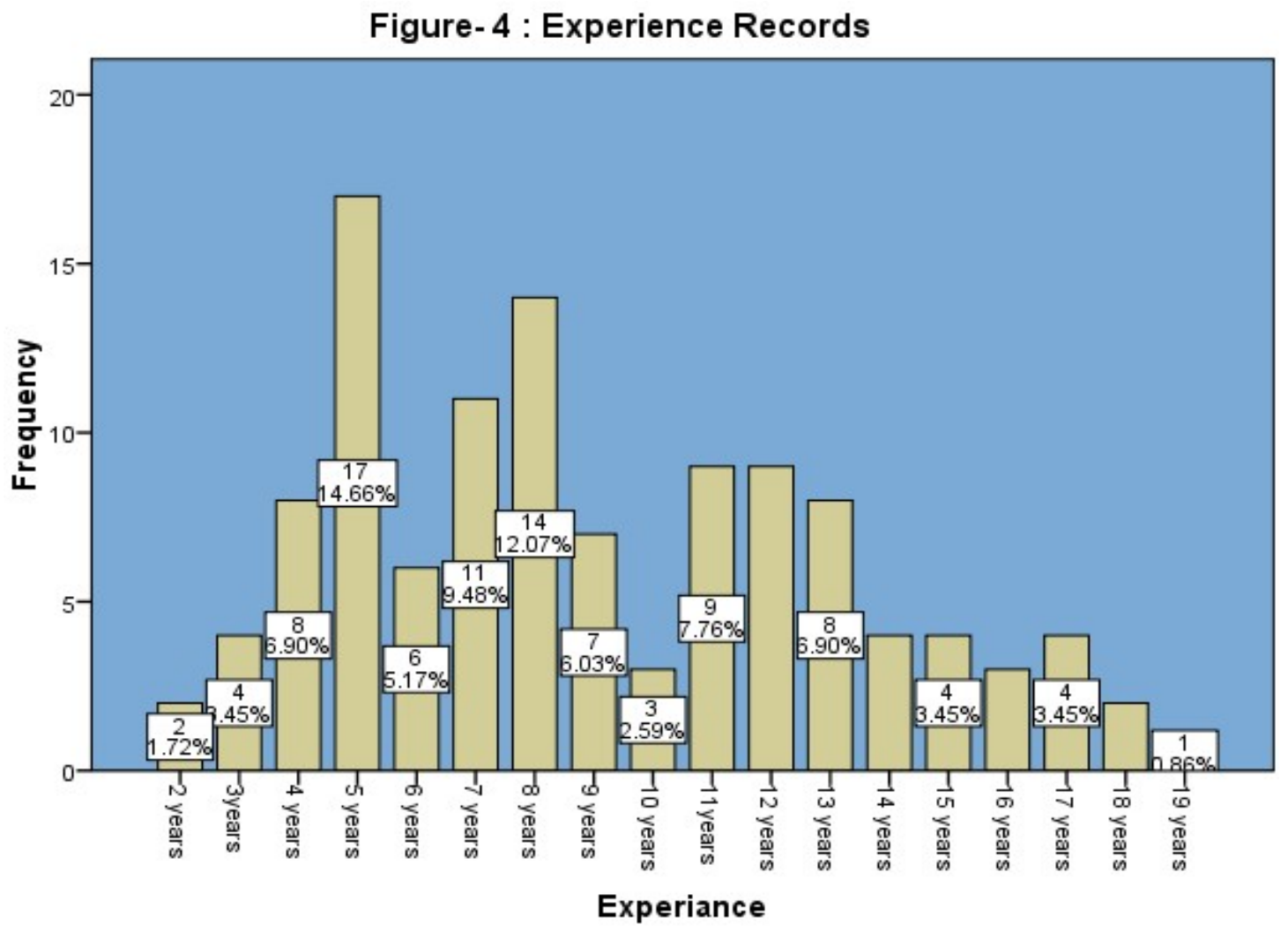

\section{Part-B: Data Analysis}

This section of analysis covers with the help of tables and figure that indicated the analysis which was done by the Statistical Package for Social Sciences (IBM SPSS Statistics 16) and the resultant results have been discussed accordingly. 
Table-3 indicates that there was 116 female non-teaching staff participated in the study. The results of all the averages such as mean, median and mode are much closed with each other that shows a good sign. The standard deviation is also indicated that the efficiency of the non-teaching female employees may be improved by using the tool of motivation by the management in various departments of the University of Karachi.

Table - 3

Motivated female employees

\begin{tabular}{|l|l|r|}
\hline \multirow{2}{*}{ AN } & Valid & 116 \\
\cline { 2 - 3 } & Missing & 0 \\
\hline Mean & 4.4052 \\
\hline Median & 5.0000 \\
\hline Mode & 5.00 \\
\hline Std. Deviation & .92293 \\
\hline
\end{tabular}

Table-4, and figure-5, below depicted that the survey report got from the respondents of the sample population by distributing closed-ended questionnaire among them that covered of eleven questions and as per the best efforts of the researchers it was tried to find out the valuable opinions of the respondents regarding all the facts that were asked through the questionnaire.

Table - 4

Motivated Female Employees

\begin{tabular}{|l|l|c|c|c|c|}
\hline & & Frequency & Percent & Valid Percent & Cumulative Percent \\
\hline Valid & Strongly Disagree & 2 & 1.7 & 1.7 & 1.7 \\
\cline { 2 - 6 } & Disagree & 6 & 5.2 & 5.2 & 6.9 \\
\cline { 2 - 6 } & Neutral & 5 & 4.3 & 4.3 & 11.2 \\
\cline { 2 - 6 } & Agree & 33 & 28.4 & 28.4 & 39.7 \\
\cline { 2 - 6 } & Strongly Agree & 70 & 60.3 & 60.3 & 100.0 \\
\cline { 2 - 6 } & Total & 116 & 100.0 & 100.0 & \\
\hline
\end{tabular}

From the table-4, it is indicated that all of the expected respondents have $100 \%$ participated in the survey and shared their opinions regarding the applying tool of motivation for making the development and innovation in the organizations and specially in public sector such in the University of Karachi and making the change not only in productivity of the organization but in overall in the working environment and in behavior of female employees.

The figure-5 depicted that the non-teaching female staff of the University of Karachi is the best example of those female employees who are demotivated due to some sort of personal and family issues, managerial and official issues and social issues that have to face by these employees and due to such issues their working life, as well as their personal lives, have disturbed. The participation of the respondents showed that all of the non-teaching female employees who have demotivated due to the effect of any reasons of issues as are mentioned above, they wanted to get rid of from their problems and wanted 
to spend their normal and happy working life if the management starts to use the motivation as a tool for organizational development and change.

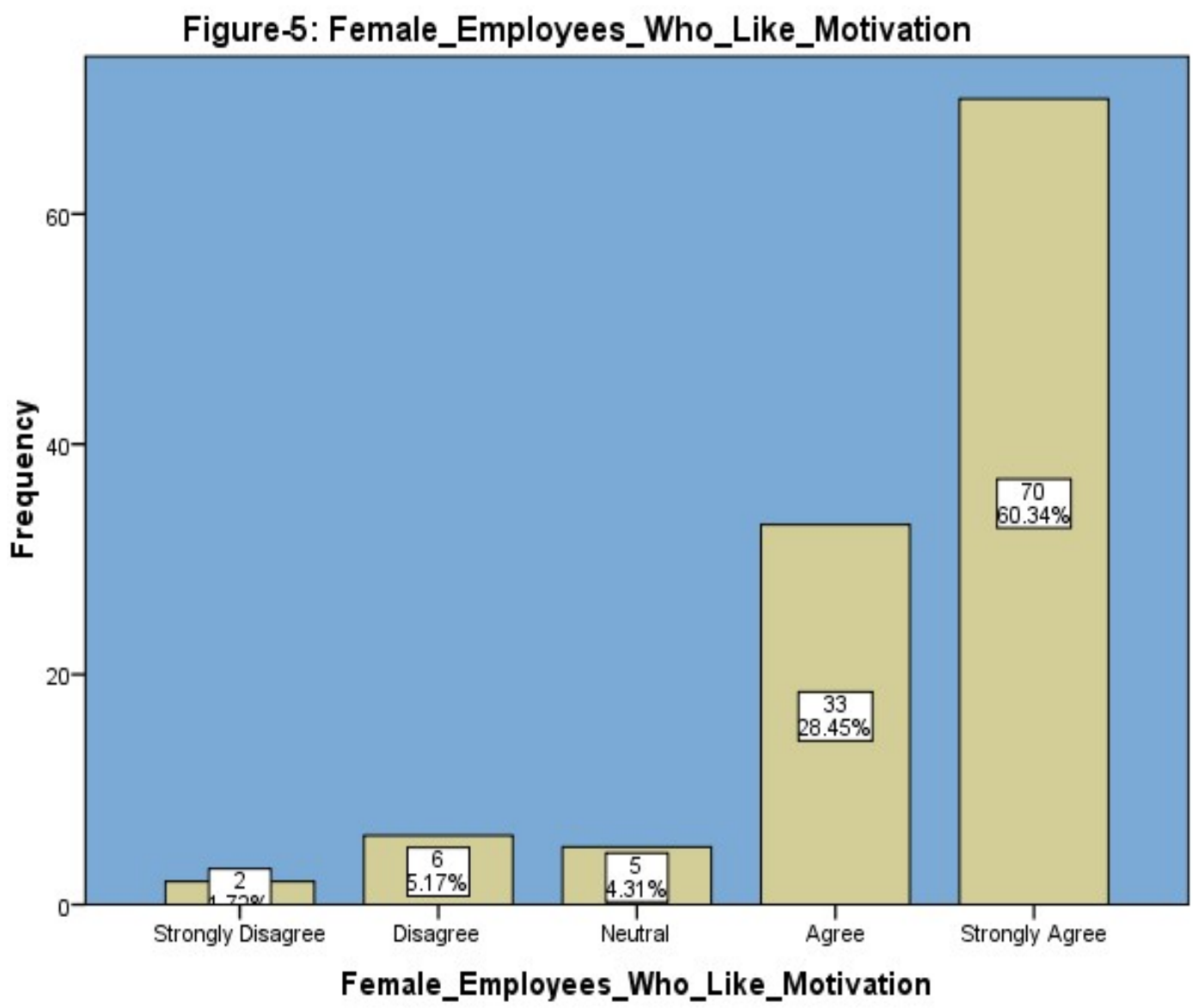

The survey report showed that among the total of 116 non-teaching female employees, only 2 females employees responded as strongly disagree and 6 female employees disagreed with the concept of motivation, and similarly, 5 females chose no side and remained neutral, while 33 females who were $28.45 \%$ of the total sample population, answered as agree and 70 females chose the strongly agree option that constitutes of $60.34 \%$ of the total sample population. It means that the majority of the sample population of the study acknowledged and recognized the concept of using of the motivational tool as the organizational development and change in the organizations and rejected the Null Hypothesis and Accepted the Alternate Hypothesis. That is means that research results are fully matching with and accepting the issues of non-teaching female employees that were highlighted by the researchers and were discussed in the problem statement of the study. 


\section{Conclusions}

The main conclusions that were drawn in the paper are appended below:

1. From the survey conducted in the various departments of the University of Karachi, it is concluded that most of the non-teaching female employees are demotivated due to their personal and family issues, management and official issues, and ethical issues such as women harassments, gender-biased, family biased, and geographical biased, etc. and are unable to perform their duties efficiently and effectively.

2. It is indicated from the results of the study that to keep the female workers intact to the association and to keep the enthusiasm in working activities, motivation acts as the catalyst that increases the performance of a working female employee as it is proved from the responses of the respondents. The survey report showed that from the total of 116 non-teaching female employees, 33 females from the total sample population agreed, and 70 females strongly agreed with applying the tool of motivation in their working lives. It means that the from a total of 116 respondents, $(33+70=103) 103$ respondents were in the favor of the study they acknowledged and recognized thatmotivation works as an innovative tool for female employees in organizational development. Their voting rejected the Null Hypothesis and Accepted the Alternate Hypothesis. It is proof for focusing on the issues of non-teaching female employees which were discussed in the problem statement of the study,

3. It is also noted that working in similar conditions and environment, each female worker has various sets of targets and objectives that is why every employee needs a motivational tool as per her need and satisfaction. For example, in some cases, female employees are motivated by the money related rewards, but in other cases, they may be motivated by giving them the appreciation letters or awards. It depends upon the management that how they can motivate their female employees by using the right motivational tool for the right employees in the existing scenario.

\section{Recommendations}

In developing countries like Pakistan, humiliation and unreliable nature towards public organizations is the actual reason for the failure of institutions and economy. Female employees of public universities such as the University of Karachi are stereotyped and drowsy towards the tasks allocated to them. Based on the study it is recommended that the motivation of female employees in the public sector universities or organizations can act as an innovative tool for organizational development and change in the following ways:

- Introduce monetary rewards, for example, promotions, increment in pay and lodging and voyaging recompenses as they should be the broad factors that can motivate 
female workers. Better motivating forces and rewards can convert a system into better administration.

- Intangible rewards, for example, admiration inward functions, titles, for example, the best worker of the month/year and acknowledgment by giving the due credits to the female employees.

- Practice the system of accountability and responsibility out in the public universities that can help to enhance the standard of the institution.

- Involve female employees in basic leadership with the goal that they feel esteemed and contribute towards the development of the organization and change.

- Introduce workshops and projects for keeping the female staff continually refreshed about the most recent changes occurring in the world.

\section{References}

Accel-Team. (2010). Employee Motivation. Retrieved from http:/www.accelteam/ motivation/intro.html

Ahlstrom, D., Bruton \& Garry, D. (2009). International Management: Strategy and Culture in the Emerging World. South-Western Cengage Learning.

Balk, W. L. (1974). Why Don't Public Administrators Take Productivity More Seriously? Public Personnel Management, vol.3:4, pp.318-324.

Behn, R. D. (1995). The Big Questions of Public Management. Public Administration Review, vol.55:4, pp.313-324.

Bevan, S., Barber, L. \& Robinson, D. (1997). Keeping the Best: A Practical Guide to Retaining Key Employees. Institute for Employment Studies, IES Reports 337.

Bowey, A. (2005). Motivation: The Art of Putting Theory into Practice. European Business Forum, vol.20, pp.17-20.

Bruce, A. \& Pepitone, J. S. (1998). Motivating Employees, A Briefcase Book. McGraw-Hill Professional. https://iopscience.iop.org/article/10.1088/1757-899X/65/1/ 012032/pdf.

Buelens, M. \& Broeck, H. V. (2007). An Analysis of Difference is Work Motivation between Public and Private ector Organizations. Public Administration Review, vol.67:1, pp.65-74. 
Buelens, M. \& Van den Broeck, H. (2007). An Analysis of Differences in Work Motivation between Public and Private Sector Organizations. Public Administration Review, vol.67:1, pp.65-74.

Christensen, P. (2002). Motivational Strategies for Public Managers: The Budgetary BeltTightening Precipitated by the Recession has Placed Renewed Emphasis on the Importance of Employee Motivation. Government Finance Review, http://findarticles.com/p/articles/mi_hb6642/is_2_18/ai_n28910543/?tag=content; coll.

Danish, R. Q. \& Usman, A. (2010). Impact of Reward and Recognition on Job Satisfaction and Motivation: An Empirical Study from Pakistan. International Journal of Business and Management, vol.5:2, pp.159-167

Hackman, J. R. \& Oldham, G. R. (1976). Motivation through the Design of Work: Test of a Theory. Organizational Behavior and Human Performance, vol.16:2, pp.250-279.

Iqbal, M. Z., Arif, M. I. \& Abbas, F. (2011). HRM Practices in Public and Private Universities of Pakistan: A Comparative Study. International Education Studies, vol.4:4, pp.215-222.

Irum, S., Sultana, A., Ahmed, K. \& Mehmood, N. (2012). Work Motivation Differences in Public and Private Sector (A Study of Higher Education Institutes in Pakistan). Institute of Interdisciplinary Business Research, vol.4:6, pp.646-661.

It's Always About The Boss (November 25, 2009). Business Journal, pp. 10-13, https://news.gallup.com/businessjournal/124481/always-boss.aspx

Jurkiewicz, C. L., Massey, T. K. \& Brown, R. G. (1998). Motivation in Public and Private Organizations: A Comparative Study. Public Productivity \& Management Review, vol.21;3, pp.230-250.

Khalid, S., Irshad, M. Z. \& Mahmood, B. (2010). Job Satisfaction among Academic Staff: A Comparative Analysis between Public and Private Sector Universities of Punjab, Pakistan. International Journal of Business and Management, vol.7:1, pp.126-136.

Landy, F. J. \& Conte, J. M. (2010). Work in the 21st Century: An Introduction to Industrial and Organizational Psychology. 3rd ed., McGraw Hill. 
Latham, G. P. (2007). Work Motivation: History, Theory, Research and Practice. Sage Publications, Inc.

Leonard, B. (2009). Why Do Public Employees Desire Intrinsic Nonmonetary Opportunities? Public Personnel Management, vol.38:3, pp.15-37.

Lyons, S. T., Duxbury, L. E. \& Higgins, C. A. (2006). A Comparison of the Values and Commitment of Private Sector, Public Sector and Parapublic Sector Employees. Public Administration Review, vol.66:4, pp.605-618.

Malik, M. E. \& Danish, R. Q. (2010). Impact of Motivation to Learn and Job Attitudes on Organizational Learning Culture in a Public Service Organization of Pakistan. $A$ Research Journal of South Asian Studies, vol.25:2, pp.217-235.

Malik, P. D., Nawab, D. S., Naeem, B. \& Danish, R. Q. (2010). Job Satisfaction and Organizational Commitment of University Teachers in Public Sector of Pakistan. International Journal of Business and Management, vol.5:6, pp.17-26.

Mitchell, T. R. (1982). Motivation: New Directions for Theory, Research and Practice. The Academy of Management Review, vol.7:1, pp.80-88.

Nawaz, B. \& Muazzam, A. (2015). Performance Related Pay of University Employees: A Comparison of Public and Private Sector Universities of Pakistan. Pakistan Business Review, vol.17:1, pp.183-200.

Perry, J. L., Mesch, D. \& Paarlberg, L. (2006). Motivating Employees in a New Governance Era: The Performance Paradigm Revisited. Public Administration Review, vol.66:4, 505-514.

Re'em, Y. (2010). Motivating Public Sector Employees:An Application-Oriented Analysis of Possibilities and Practical Tools. Hertie School of Governance, https://pdfs.semanticscholar.org/d364/8f7a3d4021ea00a92cf5f2d2f9cdcb643ca7.pdf

Robison, J. (2010). Disengagement Can Be Really Depressing. Retrieved from http://gmj.gallup.com/content/127100/disengagement-really-depressing.aspx

Stajkovic, A. D. \& Luthans, F. (2003). Behavioral Management and Task Performance in Organizations: Conceptual Background, Meta-Analysis and Test of Alternative Models. Personnel Psychology, vol.56:1, pp.155-194. 
Vandenabeele, W. (2007). Toward a Public Administration Theory of Public Service Motivation. Public Management Review, vol.9:4, pp.545-556.

WB. (2016). World Bank Indicators, https://databank.worldbank.org/source/worlddevelopment-indicators

Wright, B. E. (2001). Public Sector Work Motivation: Review of Current Literature and a Revised Conceptual Model. Journal of Public Administration and Theory, vol.11:4, pp.559-586.

Zia-ur-Rehman, M., Faisal, H. \& Khan, R. A. (2015). In Public Sector Organizations, How the Performance of Employees is Influenced by the HR Practices-Analyzing the Perspective. Journal of Managerial Sciences, vol.9:1, pp.49-68. 


\section{SURVEY QUESTIONNAIRE}

\section{APPENDIX-A}

Motivation works as an innovative tool for female employees in organizational development and change: "A case study of Karachi University's female employees." Dear Respondent:

I, Ph.D. student of University of Karachi, Pakistan, am conducting a research on the aforementioned topic and I am in the process of data collection. You are requested to spare your few precious minutes for filling out the questionnaire in your hand. The information provided by you will be used purely for academic purpose and I will maintain confidentiality of your opinion expressed for this research. Thank you for cooperation and your time.

Name:

\section{SECTION ONE-BASIC INFORMATION}

Age: years

Gender: Male/Female/Other

Education: Under Matric/Matric/Intermediate/Graduate/Post Graduate Department:

Working Experience: ___ Years

SECTION-TWO- MOTIVATION WORKS AS AN INNOVATIVE TOOL

Please encircle one number per statement to indicate your view towards the given questions, where 1 means that you strongly disagree, 2 means that you disagree, 3 means that you are neutral, 4 means that you agree, and 5 means that you strongly agree.

\begin{tabular}{|c|l|l|l|l|l|l|}
\hline & \multicolumn{1}{|c|}{ Motivation Cures To Demotivated Female Employees } & \multicolumn{4}{|c|}{ Your Choice } \\
\hline 1 & Demotivated female employees cannot show the good performance. & 5 & 4 & 3 & 2 & 1 \\
\hline 2 & The lack of motivation in female employees affects the working targets. & 5 & 4 & 3 & 2 & 1 \\
\hline 3 & Monetary rewards system is a cures the demotivated female employees. & 5 & 4 & 3 & 2 & 1 \\
\hline 4 & Intangible rewards system improves the working efficiency of the workers. & 5 & 4 & 3 & 2 & 1 \\
\hline 5 & Delayed working tactics shows the demotivation in employees. & 5 & 4 & 3 & 2 & 1 \\
\hline 6 & The demotivated employees want to leave the organization earlier. & 5 & 4 & 3 & 2 & 1 \\
\hline 7 & The motivational tool helps in organizational development and change. & 5 & 4 & 3 & 2 & 1 \\
\hline 8 & The demotivation in employees affects their working productivity. & 5 & 4 & 3 & 2 & 1 \\
\hline 9 & The motivated female employees can handle managerial easily. & 5 & 4 & 3 & 2 & 1 \\
\hline 10 & Demotivated female employees never do the innovative tasks. & 5 & 4 & 3 & 2 & 1 \\
\hline 11 & The motivated female employees finish their work in time. & 5 & 4 & 3 & 2 & 1 \\
\hline
\end{tabular}

Thank you very much for your fruitful response.

Dr. Mariya Baig is an Assistant Registrar in the Department of Examination, University of Karachi.

Muhammad Siddique is Lecturer in the PN School of Logistics, PNS Karsaz, Karachi.

Prof. Dr. Abu Zar Wajidi is Director in the Institute of Health \& Business Management (IOHBM), Jinnah Sindh Medical University. 